\title{
Service Quality is Related to Loyalty of Nursing Care Services Based on SERVQUAL Theory and the American Customer Satisfaction Index (ACSI)
}

\author{
Pratiwi Yuliansari \\ Master of Nursing Students \\ Faculty of Nursing, Universitas Airlangga \\ Surabaya, Indonesia \\ tiwi173@gmail.com
}

\author{
Nursalam \\ Faculty Of Nursing, Universitas Airlangga \\ Kampus C Mulyorejo \\ Surabaya, Indonesia \\ Ahsan \\ Nursing Science \\ Faculty of Medicine Universitas Brawijaya \\ Malang, Indonesia
}

\begin{abstract}
Nurses have an important role in the delivery of services that will always be remembered by the client. The competition this excellent service delivery has shifted the hospital functions as a social service into the social economy. This study aims to assess the relationship between the quality of service perceived by peanggan on customer loyalty in the hospital. This study is correlational survey design. The population is all customers Hospital outpatient unit Amelia Pare, Kediri with a total sample of 86 respondents are determined by simple random sampling. The variable in this study is the quality of service and customer loyalty. Data were collected using questionnaires and then analysed using Pearson statistical test with a significance value of $p<0.05$. Data were obtained from the results of the study explained that there is a positive relationship between the variables of quality and loyalty of nursing services in outpatient unit with a significant value of $p=$ 0.000. Customer loyalty can be judged by whether someone will reuse the same service in the future, and have no intention to move to other service providers are similar, it is certainly very in touch with the service they receive when making a purchase, whether such services qualified or not. Customers who confidently hand over her health problems can also be said to be loyal to the Hospital, and willing to participate and improve the quality of service hospital with a critique or suggestions when the service made a mistake and promoted the Hospital which will certainly benefit the Hospital itself.
\end{abstract}

Keywords - Service quality, loyalty, ACSI, Nursing Services

\section{INTRODUCTION}

The hospital stands as health care providers have high competition in providing quality service [1]. The shift in the purpose of the hospital services of social organisation into a socio-economic organisation requires the management to be able to retain clients or customers to compete with other hospitals [2]. Service must be performed according to standard and meet the quality norms oriented to the interests of consumers, which is required by consumers, by the wishes of the people are increasingly growing [3].
The challenge for healthcare providers is how to capture and use the information to productively improving the quality, safety and accessibility of health care service system for consumers, complaints and other comments from consumers is a valuable learning tool [4]. Instead, it becomes a threat when patients are not satisfied with the services provided to convey the bad experiences of others or even some silent, leaving the service provider and switch to another hospital so that customers become loyal [5].

Consumer reaction to the failure of services can be seen from two things, namely to survive or move to another service provider. In the marketing literature services, consumer reaction to the failure of services embodied in the form of complaining behaviour (behavioural complaints) and brand switching (switching to another service provider) [6].

Satisfaction and loyalty inpatients in Dedi Jaya Hospital Brebes obtained four kinds of relationship between satisfaction and loyalty inpatients Dedi Jaya Hospital. Most respondents $(43.3 \%)$ were in the category of failure that customers dissatisfied and disloyal category. Forced loyalty (loyal enforced) i.e., customers who are not satisfied but loyal, defector category (pedestrian) that is customer satisfied but not loyal and successes category is a loyal customer and the possibility of positive word of mouth [7].

The determining factors of customer loyalty are the quality of service, trust, and customer satisfaction. Customer confidence can indicate that the service is quality so as to create their loyalty [8].

The importance of improving the quality of care role is to build relationships with clients [9]. Positive perceptions formed on the customers' service quality will generate trust and the decision to use the health services later in life when the client is experiencing the same problems and new [10].

Customers who are satisfied with the quality of goods or services provided, it will cause that customer loyalty increased 
customer buying interest and keep customers loyal to the company otherwise occur due to a decrease in the number of customers shift of customers to a competitor [8].

Satisfied least experience of someone getting treatment at the Hospital will determine whether a person will use the Hospital again or not. Measurement and quality management is the most important in service industries, including health care. [11].

Assessing quality relationships with loyalty services nursing services is expected to help service providers. The Hospital determine the best strategy for maintaining trust and consumer concerns that the patient and family to feel satisfied with the nursing care given and to participate in efforts to improve the quality of service the Hospital.

Loyalty services nursing services is expected to help service providers which in this case is the Hospital to determine the best strategy for maintaining trust and consumer concerns that the patient and family to feel satisfied with the nursing care given and to participate in efforts to improve the quality of service of this hospital.

\section{METHODS}

This type of research is correlational survey design, where research is directed to examine the relationship between variables. Researchers are looking for, describe a relationship, introduce and test based on the existing theory [12]. Samples are customers outpatient unit Amelia Pare Hospital in the period 15 to 24 March 2017. The predetermined inclusion criteria took the sample are minimal customer has used the service in Amelia RS 2 times, adults aged over 20 years, can read and write. The sampling technique in this research is the type Simple Random Sampling Probability sampling. The research variables were collected service quality with a modification of the theory os questionnaire SERVQUAL and customer loyalty by using questionnaires modification of [13]. The collected data were analysed using Pearson statistical test with a significance value of $\mathrm{p}<0.05$.

\section{RESULT}

In this section will be presented the results of studies showing the nursing service quality, customer loyalty and relationship between the two variables.

TABLE I. QUALITY OF SERVICES IN MARCH 2017 (N-86)

\begin{tabular}{cccccccc}
\hline No. & $\begin{array}{c}\text { The Quality of } \\
\text { Nursing } \\
\text { Services }\end{array}$ & Good & & Bad & \multicolumn{2}{c}{ Total } \\
\hline & & $\sum$ & $\%$ & $\sum$ & $\%$ & $\sum$ & $\%$ \\
\hline 1. & Reliability & 42 & $49 \%$ & 44 & $51 \%$ & 86 & $100 \%$ \\
\hline 2. & Assurance & 40 & $47 \%$ & 46 & $53 \%$ & 86 & $100 \%$ \\
\hline 3. & Tangible & 42 & $49 \%$ & 44 & $51 \%$ & 86 & $100 \%$ \\
\hline 4. & Emphaty & 48 & $56 \%$ & 38 & $44 \%$ & 86 & $100 \%$ \\
\hline 5. & Responsiveness & 46 & $53 \%$ & 40 & $38 \%$ & 86 & $100 \%$ \\
\hline
\end{tabular}

TABLE II. CUSTOMER LOYALTY ON MARCH 2017(N-86)

\begin{tabular}{cccccccc}
\hline No. & $\begin{array}{c}\text { Customer } \\
\text { loyalty }\end{array}$ & \multicolumn{2}{c}{ Loyal } & \multicolumn{2}{c}{ Not Loyal } & \multicolumn{2}{c}{ Total } \\
\hline & & $\sum$ & $\%$ & $\sum$ & $\%$ & $\sum$ & $\%$ \\
\hline 1. & Repeat Buying & 50 & $58 \%$ & 36 & $42 \%$ & 86 & $100 \%$ \\
\hline 2. & Retention & 42 & $49 \%$ & 44 & $51 \%$ & 86 & $100 \%$ \\
\hline 3. & Referral & 47 & $55 \%$ & 39 & $45 \%$ & 86 & $100 \%$ \\
\hline
\end{tabular}

TABLE III. THE RELATIONSHIP OF QUALITY SERVICES WITH CUSTOMER LOYALTY

\begin{tabular}{ccccc}
\hline & \multicolumn{2}{c}{ Customer Loyalty } & Total \\
\cline { 3 - 5 } & Loyal & $\begin{array}{c}\text { Not } \\
\text { Loyal }\end{array}$ & \\
\hline Quality of Services & Good & 33 & 17 & 50 \\
\cline { 2 - 5 } & Bad & 5 & 31 & 36 \\
\hline Total & & 38 & 48 & 86 \\
\hline
\end{tabular}

TABLE IV. THE TEST OF RELATIONSHIP SERVICES QUALITY WITH CUSTOMER LOYALTY

\begin{tabular}{ccrr}
\hline & Kualitas & $\begin{array}{c}\text { Loyalitas } \\
\text { Layanan }\end{array}$ & $.518^{* *}$ \\
\hline $\begin{array}{c}\text { Quality of } \\
\text { Services }\end{array}$ & $\begin{array}{c}\text { Pearson } \\
\text { Correlation }\end{array}$ & 1 & .000 \\
\hline & Sig (2-tailed) & & .128 \\
\hline & Covariance & .246 & 1 \\
\hline Customer & Pearson & $.518^{* *}$ & \\
Loyalty & Correlation & .000 & .250 \\
\hline & Sig (2-tailed)
\end{tabular}

The value of the five dimensions of service quality obtained from questionnaires given to 86 respondents where empathy is considered good by $48(56 \%)$ of respondents as a dimension of quality to the highest point and 38 (44\%) of respondents still rate poorly on the element of empathy. Aspect of assurance is an element of quality of service with the lowest value of the results obtained as many as $40(47 \%)$ of respondents, followed by reliability and tangible, ie respectively by $42(49 \%)$ stating good, whereas $44(51 \%)$ of respondents that the reliability aspects and the physical evidence at the hospital is still bad (Table 1).

Table 2 shows that 51 (59\%) of respondents were loyal would help in the promotion of the hospital and cooperate for the good of the hospital. $58 \%$ of respondents will look to use those services. However, there are $44(51 \%)$ of respondents who have a tendency to move the nursing service to another provider.

The total of 33 respondents considers nursing services in hospitals and the quality Amelia will be loyal to the service at the Hospital, as many as 31 respondents stated that the quality of service is bad and will not be loyal to the Hospital. Five respondents stated that poor service quality would remain loyal to the hospital, and 17 customers are saying good service but chose not to be loyal to the hospital or have intentions to move or would not recommend the service at the Hospital on others (Table 3). 
Table 4 shows the significant value of the relationship between the variables of service quality with customer loyalty variable has a value of $\mathrm{p}=0.000$, which means $<0: 05$.

\section{DISCUSSION}

Based on data obtained from the study a significant correlation between the quality of services with customer loyalty in nursing services. In the American Customer Satisfaction Index stated that the quality of goods or services could be measured based on the customer's experience when using the goods or services if the quality of the perceived positive or both can lead to customer loyalty. Nursing services for key services in the hospital will determine whether the client will re-use the service again in the future or not, it is necessary to maintain the quality of nursing services [14].

The theory of SERVQUAL stated that the concept of quality of service expected and perceived is determined by the quality of service that consists of five interrelated elements, namely reliability, assurance, tangible, empathy, responsiveness [15]. The results stated elements of assurance (assurance) have good ratings are the lowest compared to other elements. By assurance (assurance) services must be provided in accordance commitment to the service provider so that customers feel confident, safe and convenient to use these services. Supported by service form physically received by the client in the form of facilities and equipment in providing services, by the ability to master technology, things like this will be accepted by the customers as tangible aspects (physical evidence) that affect service quality [16]. Client assessment of the physical condition of receipt of services that can leave a positive impression on the ability of service providers [17].

Every employee that provides fast, accurate, easy, seamless and quality will be able to give satisfaction. The organisation of work that can be trusted and believed capable of giving satisfaction to customers would be followed by work ethics and work culture by the application of the vision, the mission of an organisation providing services [18].

Services delivered with integrity and totality will provide many benefits to the service provider itself [19]. In the long run, will be more profitable to keep customers loyal rather than constantly seeking new customers to replace customers who leave. Customers are very satisfied with the service ever experienced will spread positive stories of mouth and instead will be walking and talking advertisement for a company, this will reduce the cost to attract new customers.

Customer or patient trust is very important to create their loyalty [9]. The loyalty is the willingness of a person to make an investment or sacrifice someone to strengthen relationships with enterprise customers is not necessarily loyal customers are satisfied with the service, but a satisfied customer will be loyal to the service providers [20].

Related Research loyalty with the title Configure algorithms of patient satisfaction, participation in diagnostics, and treatment decisions' influences on hospital loyalty using the dimensions of patient satisfaction, patient involvement in decision making at every medical treatment or care and patient loyalty. The loyalty of the patient is not only influenced by patient satisfaction with the quality of service alone, but can also be influenced by patient involvement in the determination of the diagnostic and decision-making processes medical treatment and care, but the three variables above also have a significant relationship together [10].

Loyal customers will be an asset to the hospital as a provider. Loyal customers will come to give full attention to the Hospital to maintain quality and improve it. He will not hesitate to give constructive criticism and suggestions for the good of the Hospital. This customer has also become a medium for hospitals that would recommend to others to use the same service.

The quality of nursing care services is supposed to be the form of services that do not doubt the quality. Nursing services are bringing the image of the Hospital where the service will be remembered by the client and determine whether these clients will come back or not as a form of their loyalty and have no intention to move to a nursing service provider to another.

\section{CONCLUSION}

Product or service quality was measured on whether the customer can purchase full satisfied or not. Customers who are satisfied will be a service and then will come back to that service provider when it got the same problem or new, return them continuously to form a bond which is called loyalty to be a true partner service providers who will always be ready to assist their providers in maintaining even improve the quality of services to the satisfaction of its customers.

Based on customer statements obtained through questionnaires on quality of service and loyalty they expected the hospital to maintain and improve the quality of nursing services from the five aspects of quality or that is responsiveness, assurance, tangible, empathy, and reliability. Hospital to conduct a survey of nursing service quality on a regular basis annually.

Five aspects of perceived quality that customers can represent a picture of nursing care provided by nurses, so that it can be input for nurses and nursing students to improve and enhance the competence of nursing. The perceived quality associated with responsiveness, empathy, service assurance and reliability owned so as to meet the needs of clients as customers and maintain the trust and loyalty of customers. Further studies should be done related to customer loyalty models.

\section{REFERENCE}

[1] E. Trimumpuni, “Analisis Pengaruh Persepsi Mutu Pelayanan Asuhan Keperawatan Terhadap Kepuasan Klien Rawat Inap Di RSU Puri Asih Salatiga," Universitas Diponegoro Semarang, 2009.

[2] N. Afriani, "Analisi Penanganan Keluhan Pelanggan Oleh Instalasi Pemasaran Dan Humas Rumah Sakit Umum Pusat Fatmawati Tahun 2012," Universitas Indonesia, 2012.

[3] K. Hanson, W. C. Yip, and W. Hsiao, "The impact of 
quality on the demand for outpatient services in Cyprus," Health Econ., vol. 13, no. 12, pp. 1167-1180, Dec. 2004.

[4] D. Brous, M. Coleman, R. Schwarz, D. Spartels, and L. Buchanan, Guide to Complaint Handling in. 2005.

[5] R. . Georson, Mengukur kepuasan pelanggan. Jakarta: PPM, 2002.

[6] F. T. Alfansi, L., Atmaja, "Konseptualisasi Dan Pemodelan Antesenden Kesetiaan Pelanggan Industri Jasa Di Indonesia," J. Natl. Conf. Manag. Res., 2008.

[7] I. . Laksono, "Analisis Kepuasan Dan Hubungannya Dengan Loyalitas Pasien Rawat Inap Di Rumah Sakit Dedi Jaya Kabupaten Brebes.," Universitas Diponegoro Semarang, 2008.

[8] T. Assumption University (Bangkok and N. Parvez, ABAC journal, vol. 29, no. 1. The University, 1993.

[9] S. Azwar, Sikap Manusia: Teori dan Pengukurannya. Yogyakarta: EGC, 2008.

[10] C.-S. Chang, S.-Y. Chen, and Y.-T. Lan, "Service quality, trust, and patient satisfaction in interpersonalbased medical service encounters," BMC Health Serv. Res., vol. 13, no. 22, 2013.

[11] Ž. Piligrimienė and I. Bučiūnienè, "Different Perspectives on Health Care Quality: Is the Consensus Possible?," Eng. Econ., vol. 56, no. 1, 2015.

[12] Notoadmodjo, Pengantar ilmu perilaku kesehatan. Jakarta: Badan Penerbit Kesehatan MasyarakatFakultas Kesehatan Masyarakat. Universitas Indonesia, 2010.

[13] D. Baba and W. Mph, "ABSTRACT Patient Loyalty versus Satisfaction: Implications for Quality and Marketing Strategies," Walden University, 2007.

[14] C. Fornell, M. D. Johnson, E. W. Anderson, J. Cha, and B. E. Bryant, "The American Customer Satisfaction Index: Nature, Purpose, and Findings," J. Mark., vol. 60, no. 4, p. 7, Oct. 1996.

[15] V. Parasuraman, A. Zeithaml, Delivering Quality Service. New York: The Free Press, 2001.

[16] D. Arisutha, Dimensi Kualitas Pelayanan. Jakarta: Penerbit Gramedia Pustaka, 2005.

[17] S. Martul, Implementasi Dimensi Kualitas Pelayanan Konsumen. Jakarta: Penerbit Sinar Grafika, 2004.

[18] Margaretha, Kualitas Pelayanan: Teori dan Aplikasi. Jakarta: Penerbit Mandar Maju, 2003.

[19] L. K. Lovelock,Christopher.H dan Wright, Manajemen Pemasaran Jasa. Jakarta: PT Index, 2005.

[20] F. F. Reichheld, "The One Number You Need to Grow The One Number You Need to Grow The Idea in Brief The Idea in Practice," Harvard Bussines Rev., vol. 81, no. 12, pp. 46-54, 2003. 